УДК 343.841(477)

DOI https://doi.org/10.32782/2409-4544/2020-1/18

3. Журавська

\title{
Право засудженого на ізольоване тримання у місцях позбавлення волі як один із заходів забезпечення безпеки
}

У статті розглянуті питання права засуджених на ізольоване утримання під час відбування покарання у виправних колоніях закритого типу для забезпечення їх безпеки. Відзначено, що в нормативно-правових актах України не врегульовані деякі питання поняття «безпечне місце» $\mathrm{i}$ процедура, пов'язана із забезпеченням особистої безпеки засуджених. Запропоновано поняття «безпечне місце в установах виконання покарань», під яким слід розуміти будь-яке спеціально обладнане приміщення, включаючи окрему камеру дисциплінарного ізолятора, приміщення камерного типу або карцеру, доступ до якої для сторін конфлікту, інших засуджених або персоналу колонії без спеціального дозволу обмежений або заборонений, і яка максимально забезпечує особисту безпеку засудженого, який відповідно до закону звернувся за допомогою. У статті обгрунтовано пропозицію доповнити ст. 10 Кримінально-виконавчого кодексу обов'язком служби персоналу органів і установ виконання покарання по виявленню джерел небезпеки, які загрожують життю та здоров'ю засуджених у ході відбування покарання, а також пропозицію про доповнення Правил внутрішнього розпорядку установ виконання покарань окремим розділом про порядок переведення засудженого в безпечне місце і положеннями про зміст понять «безпечне місце в установах виконання покарань», «небезпека для життя і здоров'я засудженого». Ізоляція засуджених у формі покамерного тримання суттєво впливає на підвищення рівня безпеки засуджених. Так, відповідно до Європейських пенітенціарних правил, пріоритетним є окреме тримання засуджених, тим більше, у країнах Свропи таке утримання є звичною практикою. Жодна країна у світі не практикує тримання засуджених великими групами, окрім деяких пострадянських країн, зокрема i наша держава. У зв'язку із зазначеним, варто було б запозичити зарубіжний досвід задля дотримання міжнародних стандартів та пришвидшити перехід від казарменного способу утримання засуджених до покамерного.

Ключові слова. Засуджений, місця позбавлення волі, безпека, права засудженого, дисциплінарний ізолятор, ізоляція засудженого.

Постановка наукової проблеми та її значення. У статті здійснений аналіз нормативноправових актів та поглядів науковців, які стосуються забезпечення особистої безпеки засуджених, зокрема права засуджених на ізольоване тримання, а також запропоновані зміни до законодавства у вказаній сфері.

Аналіз досліджень цієї проблеми. В науці зазначена проблематика є об'єктом вивчення значної кількості науковців, зокрема, таких, як В. В. Василевич, О. М. Джужа, О. Г. Колб, І. О. Колб, I. М. Копотун, М. І. Лисенко, М. В. Романов, I. С. Яковець та ін. Над іiі вирішенням постійно працюють фахівці, проте, вказана проблематика потребує подальшого аналізу та вивчення.

Мета й завдання статті. Необхідність аналізу законопроектів та наукової літератури, які мають відношення до прав засуджених, зокрема ізольованого тримання, як один із заходів забезпечення особистої безпеки засуджених, для кращого розуміння вказаної проблематики з метою розроблення заходів, які були б спрямовані на вдосконалення системи заходів безпеки життєдіяльності у виправних колоніях.

Виклад основного матеріалу й обгрунтування отриманих результатів дослідження. Юридична література трактує безпеку як стан захищеності життєво важливих законних інтересів особи від будь-якої зовнішньої загрози, а забезпечення безпеки особи є однією з основних функцій держави [1, с. 42]. Засуджені нарівно 3 іншими громадянами й особами, які перебувають під юрисдикцією держави, згідно з міжнародними стандартами у галузі прав людини і громадянина, мають право на правовий і соціальний захист і держава повинна забезпечувати і їх особисту безпеку, незважаючи на тяжкість вчинених ними злочинів, ступінь суспільної небезпеки, минулу злочинну діяльність тощо. В контексті зазначеного, ч. 1 ст. 10 КВК України передбачає загальне право на особисту безпеку всіх без обмеження категорій засуджених. На думку М. В. Романова, «особиста

() Журавська 3., 2020 
безпека засуджених» - це становище засудженого як суб'єкта кримінально-виконавчих правовідносин під час відбування покарання, що створює умови його життєдіяльності, які не мають ознак агресії, непередбачуваності, неконтрольованості, сваволі та загрози з боку персоналу органу або установи виконання покарань, інших засуджених чи третіх осіб й має ефективні механізми забезпечення і захисту прав засудженого [2, с.173].

У разі наявності небезпеки для життя і здоров'я засуджених, згідно з ч. 4 ст. 10 КВК, до яких у зв'язку з їх участю у кримінальному судочинстві прийнято рішення про застосування заходів безпеки, адміністрація установи виконання покарань вживає заходів щодо забезпечення безпеки цих осіб. Крім того, до зазначених осіб можуть бути застосовані такі заходи як ізольоване тримання та переведення в іншу установу виконання покарань.

Під час реалізації переведення засуджених у безпечне місце, виникає ряд проблем, через неврегульованість у нормативно-правових актах України певних моментів. Зокрема, в ч. 2 ст. 10 КВК зазначено, що адміністрація установ виконання покарань (далі - УВП) вживає заходів до переведення засудженого в безпечне місце, проте ні на законодавчому, ні на відомчому рівнях поняття «безпечне місце» не сформовано. А це, у свою чергу, знижує рівень ефективності діяльності персоналу УВП по виконанню цього завдання та зменшує можливість забезпечення безпечних умов життєдіяльності засуджених у місцях позбавлення волі. Якщо виходити з буквального змісту Правил внутрішнього розпорядку установ виконання покарань, до безпечних місць в УВП слід віднести: окрему камеру приміщення камерного типу (ПКТ), дисциплінарний ізолятор (ДІЗО) та карцер.

Науковці дають так зване розширене тлумачення [3, с. 411] поняття «безпечне місце», і з цим варто погодитись, відносячи до нього будь-яке вільне приміщення УВП, доступ до якого сторін конфлікту, інших засуджених чи персоналу установи $є$ обмеженим або забороненим (житлові приміщення іншого відділення чи іншої дільниці, кімнати чергової частини, вільні камери ПКТ, ДІЗО, т. ін.) [4, с. 49]. Крім цього, в науці кримінально-виконавчого права виведено саме поняття «безпечне місце», під яким в УВП необхідно розуміти спеціально обладнані для цих цілей приміщення, камери ДІЗО, карцерів тощо [5, с. 215].

Варто було б, у зв'язку з цим, доповнити Правила внутрішнього розпорядку установ виконання покарань (ПВР УВП) окремим розділом щодо переводу засудженого у безпечне місце, як це визначено у ПВР УВП Російської Федерації. Вказане дозволило б вирішити питання передбачення процедури, пов' язаної із забезпеченням особистої безпеки засуджених [6, с. 74].

Отже, виходячи $з$ проведеного дослідження, можна сформулювати визначення безпечного місця в установах виконання покарань, а саме - це будь-яке спеціально обладнане приміщення, включаючи окрему камеру ДІЗО, ПКТ чи карцеру, доступ до якої сторін конфлікту, інших засуджених чи персоналу колонії без спеціального дозволу є обмеженим чи забороненим, та яка максимально забезпечує особисту безпеку засудженого, який відповідно до закону звернувся за допомогою. Обладнання таких приміщень здійснюється відповідно до вимог ПВР УВП. На відміну від попереднього, спеціальне приміщення обладнується таким чином, щоб забезпечити безпечні умови проживання в ньому засуджених, а також безпечні умови роботи (служби) для персоналу УВП. До таких, зокрема, й відносяться окремі камери ДІЗО, ПКТ та карцеру.

Як свідчить практика, неоднозначним для розуміння як засудженими, так і персоналом УВП $є$ й поняття «небезпека життю і здоров'ю». У науковій літературі такою небезпекою вважають сукупність умов і факторів, що створюють можливу (передбачену для засуджених шкоду, яка може бути здійснена лише за певних обставин) чи явну (реальне причинення шкоди) небезпеку їх життєво важливим інтересом [5, с. 213-214].

У судовій практиці, наприклад, у п. 2 постанови Пленуму Верховного Суду України від 26.04.2012 p. № 1 «Про судову практику у справах про необхідну оборону» зазначено, що при 3'ясуванні наявності загрози необхідно враховувати поведінку нападника, зокрема спрямованість умислу, інтенсивність і характер його дій, що дають особі, яка захищається, підстави сприймати загрозу як реальну [7, с. 236]. У свою чергу, у п. 4 постанови Пленуму Верховного Суду України від 26.0.3.1993 р. № 2 «Про судову практику в справах про злочини, пов’язані з порушенням режиму відбування покарання в місцях позбавлення волі» дано тлумачення ще одного із способів вчинення загрози для життя і здоров'я засуджених, а саме - тероризування засуджених, що стали на шлях виправлення, під яким слід розуміти застосування насильства або погрози насильства 3 метою примусити їх відмовитись від сумлінного ставлення до праці, додержання правил режиму, т.ін. [8, c. 182].

Також є джерела, в яких зазначається, що небезпека (посягання на життя і здоров’я особи) має бути дійсною, реальною та такою, що існує об'єктивно, а не лише в уяві особи, яка звернулась за 
захистом. О. О. Кваша вважає, що уявна оборона - це оборона проти уявного, але в дійсності не існуючого посягання [9, с. 51], що досить важливо з огляду визначення реальності небезпеки для життя і здоров'я засуджених, які мають право звернутися із заявою, в якій попросити забезпечити їх особисту безпеку. При цьому, якщо виходячи з буквального змісту ч. 2 ст. 10 КВК, то форма заяви може бути довільною та носити усний чи письмовий характер.

У зв’язку з вищевикладеним, варто ПВР УВП доповнити положеннями щодо змісту «безпечного місця», «небезпеки для життя і здоров'я засудженого». Також, у Правилах необхідно зазначити, що під посадовою особою органу чи установи виконання покарань, відповідно до вимог ч. 1 ст. 14 Закону України «Про Державну кримінально-виконавчу службу України», слід розуміти персонал ДКВС, а саме: особи рядового i начальницького складу; спеціалісти, які не мають спеціальних звань, та інші працівники, які працюють за трудовими договорами в ДКВС. При цьому варто зазначити, що від обов'язку по забезпеченню права засуджених на особисту безпеку жодна із категорій персоналу ДКВС не звільняється і у випадках, коли такі дії не здійснює, то притягається до передбаченої законом відповідальності у залежності від суспільно небезпечних наслідків, у тому числі по ст. 135 КК «Залишення в небезпеці» та ст. 367 КК «Службова недбалість», ін. Більш того, відповідно до вимог ст. 214 КПК «Початок досудового розслідування» відповідні посадові особи 3 числа персоналу ДКВС зобов'язані направити письмове повідомлення прокурору для внесення відомостей, викладених у заяві засудженого, до Єдиного реєстру досудових розслідувань [10, с. 12].

Ще один момент, який звертає на себе увагу, це часті випадки, коли засуджений не звертається до адміністрації колонії із заявою про виникнення небезпеки його життю і здоров’ю. Причиною може бути сподівання на власні сили чи допомогу інших засуджених, або навпаки боязнь реакції працівників УВП [5, с. 215]. У такому випадку посадові особи УВП, керуючись вимогами ст. 10 КВК, зобов'язані виявити таку небезпеку під час проведення відповідно заходів, включаючи оперативно-розшукову діяльність. Тому, варто було б доповнити ст. 10 КВК обов'язком персоналу органів та УВП щодо виявлення джерел небезпеки, що загрожують життю і здоров'ю засудженого у ході відбування покарання. Вказане базується ще й на тому, що ст. 104 КВК «Оперативно-розшукова діяльність в колоніях» передбачає покладене на оперативні підрозділи УВП завдання по забезпеченню безпеки засуджених. Співзвучне завдання закріплене також в ЗУ «Про оперативнорозшукову діяльність».

Додатковим мотивом 3 цього приводу виступають результати вивчення практики, де встановлено, що є багато причин виникнення загроз особистій безпеці засуджених в УВП. Зокрема, це конфлікт; вимоги сплати боргу, що виник внаслідок програшу в азартні ігри; особиста неприязнь; суперечності, що пов'язані з кримінальним минулим, тощо. При цьому, як вірно зробили висновок О. М. Джужа та О. І. Осауленко, їх характер для реалізації права на особисту безпеку значення не мають, головне це виникнення загрози життю і здоров’ю конкретного засудженого [5, с. 214].

Також досить багато неврегульованих питань притаманно й для іншої форми забезпечення права засуджених на особисту безпеку, а саме - щодо здійснення інших заходів до усунення небезпеки. Так, досі на рівні жодного закону чи іншого нормативно правового акту, не визначені такі заходи. Таким чином, виходячи 3 того, що перелік інших заходів, які має здійснювати будь-яка посадова особа УВП для забезпечення безпеки засудженого, який звернувся 3 такою заявою, у ч. 2 ст. 10 КВК не визначений, персонал колонії вимушений здійснювати їх на власний розсуд, враховуючи стан реальної криміногенної обстановки в установі, категорії засуджених, які відбувають покарання у виді позбавлення волі, та інші конкретні обставини. Це, наприклад, може бути ізоляція засуджених, від яких походить загроза, притягнення їх до різних видів юридичної відповідальності, переведення конфліктуючих сторін до інших УВП, тощо [4, с. 50].

Виходячи із змісту ч. 4 ст. 10 КВК, потребує видозміни й ч. 1 ст. 7 Закону України «Про забезпечення безпеки осіб, які беруть участь у кримінальному судочинстві», зокрема іiі слід доповнити ізольованим триманням особи та переведенням такої в іншу установу виконання покарань, а також переведення засудженого в безпечне місце (ч. 3 ст. 10 КВК). Такі ж зміни необхідно внести й в ст. 19 даного Закону «Забезпечення безпеки осіб, які перебувають в установах виконання покарань чи слідчих ізоляторах або у місцях із спеціальним режимом тримання».

Виходячи з зазначеного, варто було б внести у КВК ті положення, що регулюють порядок забезпечення права засуджених у ПВР УВП. Так, у п.6 XXVII розділу «Особливості зміни умов тримання засуджених до позбавлення волі» цих Правил зазначено, що у разі виникнення небезпеки життю і здоров'ю засудженого, до якого згідно із законом у зв' язку з його участю у кримінальному судочинстві прийнято рішення про застосування заходів безпеки, необхідності захисту його від розправи з боку інших засуджених або за заявою засудженого з проханням про забезпечення 
особистої безпеки, якщо він не допустив порушення режиму, а також ізоляції засудженого на час підготовки необхідних матеріалів на переведення його до іншої установи, за мотивованою постановою начальника установи дозволяється тримати його в окремій камері, ПКТ, ДІЗО та карцері на загальних підставах до закінчення перевірки, усунення небезпеки, остаточного розв'язання конфлікту або отримання наряду на переведення, але не більше 30 діб. 3 огляду цього, логічно було б даною нормою доповнити КВК України.

Привертає увагу такий аспект, як ізоляція засуджених у формі покамерного тримання, що впливає на підвищення рівня безпеки засуджених. Так, відповідно до Європейських пенітенціарних правил, пріоритетним є окреме тримання засуджених, тим більше, у країнах Європи таке утримання це звична практика. Жодна країна у світі не практикує тримання засуджених великими групами, окрім деяких пострадянських країн, зокрема і наша держава. 3 цього приводу, М. І. Лисенко виділяє наступні переваги організації ізоляції засуджених шляхом по камерного тримання:

- забезпечення індивідуалізації процесу відбування покарання;

- створення підгрунтя для індивідуальної соціально-виховної роботи із засудженими;

- ефективність під час лікування хворих засуджених, особливо це стосується заразних форм хвороб;

- реалізація засудженими природного людського бажання усамітнення;

- підвищення безпеки засудженого, зокрема й від психологічної агресії [11, с. 260].

У зв'язку із зазначеним, варто було б запозичити зарубіжний досвід задля дотримання міжнародних стандартів та пришвидшити перехід від казарменного способу утримання засуджених до покамерного.

Висновки. Враховуючи викладене, варто було б доповнити Правила внутрішнього розпорядку установ виконання покарань окремим розділом щодо переводу засудженого у безпечне місце та положеннями щодо змісту «безпечного місця», «небезпеки для життя і здоров'я засудженого». Також, доповнити ст. 10 КВК обов'язком персоналу органів та УВП щодо виявлення джерел небезпеки, що загрожують життю і здоров'ю засудженого у ході відбування покарання та внести у КВК ті положення, що регулюють порядок забезпечення права засуджених у ПВР УВП.

\section{Джерела та література}

1. Сліпченко В. І. Перспективи реформування оперативно-розшукової діяльності (в контексті розробки нового КПК України) / В. І. Сліпченко [Електронний ресурс]. - Режим доступу: http://www.corp-lguvd.ua/d120108.html.

2. Романов М. В. Право засудженого на особисту безпеку / М. В. Романов // Юридичний науковий електронний журнал. - 2014. - № 6. -С. 172-175.

3. Скакун О. Ф. Теорія держави і права: підручник / О. Ф. Скакун. - Харків: Консум, 2001. - 656 с.

4. Науково-практичний коментар Кримінально-виконавчого кодексу України / А. П. Гель, О. Г. Колб, В. О. Корчинський та ін.; за заг. ред. А. Х. Степанюка. - Київ: Юрінком Інтер, 2008. - 496 с.

5. Кримінально-виконавче право України: підручник/ О.М.Джужа, І. Г. Богатирьов, О. Г. Колб, В. В. Василевич та ін.; за заг. ред. О. М. Джужі. - Київ: Атіка, 2010. - 752 с.

6. Правила внутреннего распорядка изоляторов временного содержания, следственных изоляторов, исправительных учреждений и воспитательных колоний. - Новосибирск: Сиб. унив. изд-во, 2011. $111 \mathrm{c}$.

7. Про судову практику у справах про необхідну оборону: постанова Пленуму Верховного Суду України у кримінальних справах від 26 квітня 2002 р. № 1 // Постанови Пленуму Верховного Суду України у кримінальних справах. - (3-є вид., змін. і доп.). - К.: Видавничий дім «Скіф», 2008. C. 236-238.

8. Про судову практику в справах про злочини, пов'язані з порушеннями режиму відбування покарання в місцях позбавлення волі: постанова Пленуму Верховного Суду України від 26.03.1993 р. №2 // Постанови Пленуму Верховного Суду України у кримінальних справах. 3-є вид., змін. і доп. Київ: Видавничий дім «Скіф», 2009. - С. 181-189.

9. Кваша О. О. Уявна оборона: кримінологічно-правова кваліфікація та відповідальність: монографія / О. О. Кваша. - Луцьк: Вежа Друк, 2012. - 180 с.

10. Богатирьов I. Г., Пузирьов М. С. Методичні рекомендації щодо застосування Кримінального процесуального кодексу України органами i установами, що належать до сфери управління Державної пенітенціарної служби України / І. Г. Богатирьов, М. С. Пузирьов. - Київ: ДПтС України, 2012. - 28c.

11. Лисенко М. І. Ізоляція засуджених в умовах реформування Державної кримінально-виконавчої 
служби в Україні / М. І. Лисенко // Науковий вісник публічного та приватного права. - 2016. - № 5. C. 259-262.

Журавская С. Право осужденного на изолированное содержание в местах лишения свободы как одна из мер обеспечения безопасности. В статье рассмотрены вопросы права осужденных на изолированное содержание во время отбывания наказания в исправительных колониях закрытого типа для обеспечения их безопасности. Отмечено, что в нормативно-правовых актах Украины не урегулированы некоторые вопросы понятия «безопасное место» и процедура, связанная с обеспечением личной безопасности осужденных. Предложено понятие «безопасного места в учреждениях исполнения наказаний», под которым следует понимать любое специально оборудованное помещение, включая отдельную камеру дисциплинарного изолятора, помещения камерного типа или карцера, доступ к которой сторон конфликта, других осужденных или персонала колонии без специального разрешения ограничен или запрещен, и которая максимально обеспечивает личную безопасность осужденного, который в соответствии с законом обратился за помощью. В статье обосновано предложение дополнить ст. 10 Уголовно-исполнительного кодекса обязанностью службы персонала органов и учреждений исполнения наказания по выявлению источников опасности, угрожающих жизни и здоровью осужденного в ходе отбывания наказания, а также дополнение Правил внутреннего распорядка учреждений исполнения наказаний отдельным разделом по переводу осужденного в безопасное место и положениями о содержании понятий «безопасного места», «опасности для жизни и здоровья осужденного». Изоляция осужденных в форме покамерного содержания существенно влияет на повышение уровня безопасности осужденных. Так, в соответствии с Европейскими пенитенциарными правилами, приоритетным является раздельное содержание осужденных, тем более, в странах Европы такое содержание является обычной практикой. Ни одна развитая страна в мире не актикует содержания осужденных большими группами, кроме некоторых постсоветских стран, в том числе и наше государство. В связи с указанным, стоило бы позаимствовать зарубежный опыт по соблюдению международных стандартов и ускорить переход от казарменного способа содержания осужденных к покамерному.

Ключевые слова. осужденный, места лишения свободы, безопасность, права осужденного, дисциплинарный изолятор, изоляция осужденного.

Zhuravska Z. The Right of a Convict to Solitary Confinement in Places of Imprisonment as One of the Security Provision Measures. The article considers the issue of the convict's right to solitary confinement while serving his sentence in closed penal colonies for the sake of their safety. The study has revealed that the normative-legal acts of Ukraine do not regulate properly some issues related to the concept of «safe place», including the issue of providing a legal procedure concerning the personal safety of convicts. The author substantiates the concept of «safe place in penitentiary institutions», which should be understood as any specially equipped room, including a separate cell in a disciplinary prison, a cell-type room or solitary confinement, to which access of the parties to the conflict, other convicts or prison staff is restricted or prohibited without special permission, and which maximizes the personal safety of the convicted, who in accordance with the law sought help. The article substantiates the proposal to supplement Article 10 of the Criminal-Executive Code with the provision about the duty of the staff of penitentiary bodies and institutions to identify sources of danger to the life and health of the convict while serving the sentence and supplementing the Rules of Procedure of the penitentiary institutions with a separate section on transferring the convict to a safe place and the provisions clarifying the content of «safe place», «danger to life and health of the convict». Isolation of convicts in the form of cell detention, which affects the level of security of convicts. Thus, according to the European penitentiary rules, the priority is the separate detention of convicts, especially in European countries such detention is a common practice. No country in the world practices holding large groups of convicts, except for some post-Soviet countries, including our state. In this regard, it would be worthwhile to borrow foreign experience in order to comply with international standards and accelerate the transition from the barracks method of detention to the cell.

Key words: convict, places of imprisonment, security, rights of the convict, disciplinary isolator, confinement of the convict. 